\title{
Bermain Terapeutik Clay Menurunkan Tingkat Kecemasan Pada Anak Usia Prasekolah Saat Tindakan Injeksi
}

\author{
Anisa Oktiawati ${ }^{1}$, Wisnu Widyantoro ${ }^{2}$, Ayu Mey Fahmi Fardlillah ${ }^{3}$ \\ ${ }^{1}$ Dosen Program Studi D III Keperawatan STIKes Bhakti Mandala Husada Slawi \\ Email : anisaoktiawati1586@gmail.com \\ ${ }^{2}$ Dosen Program Studi S1 Keperawatan STIKes Bhakti Mandala Husada Slawi \\ ${ }^{3}$ Mahasiswa Program Studi S1 Keperawatan STIKes Bhakti Mandala Husada Slawi
}

\section{ABSTRACT: PLAYING CLAY THERAPEUTIC REDUCES ANXIETY LEVELS IN PRE- SCHOOL AGE DURING INJECTION ACTION}

Background: Many children who are hospitalized have anxiety. The child's anxiety was caused by the injection. Anxiety in children is characterized by a refusal reaction, the child is afraid of the treatment given, the child often cries and is not cooperative with health workers. For this reason, clay therapy is given, where playing can make children happier and more comfortable so that stress and tension can be avoided.

Objective: To determine the effect of clay therapy on anxiety levels in preschool children during injection in the Orchid room of dr. Soeselo Slawi.

Research Methods: This type of research is quantitative, quasi experimental design with one group pretest and posttest design approach. The sample in this study were 20 preschool children. The instrument used was an observation sheet to determine anxiety using the Spence Children Anxiety Scale. Data analysis was univariate (frequency distribution) and bivariate (Wilxocon test). Results: The results of the Wilcoxon test using a computer program at an error rate of $5 \%(\rho-0.05)$ were obtained $\rho$ value $=0.002$ so that $\rho$ value $<\rho$ namely $(0.002<0.05)$ which means that $\mathrm{Ha}$ is accepted and it means that there is an effect of playing therapeutic clay on the level of anxiety in preschool children during the injection in the Anggrek room RSUD dr. Soeselo Slawi.

Conclusion: there is an effect of playing therapeutic clay on the level of anxiety in preschool children during the injection in the Orchid room at RSUD $d r$. Soeselo Slawi. The recommendation from this study is that clay can be given to preschoolers to reduce anxiety during injection.

Keywords: Play, Clay, Injection, Anxiety

\footnotetext{
Anisa Oktiawati ${ }^{1}$, Wisnu Widyantoro ${ }^{2}$, Ayu Mey Fahmi Fardlillah ${ }^{3}$

${ }^{1}$ Dosen STIKes Bhakti Mandala Husada Slawi. Email : anisaoktiawati1586@gmail.com

${ }^{2}$ Dosen Program Studi S1 Keperawatan STIKes Bhakti Mandala Husada Slawi

${ }^{3}$ Mahasiswa Program Studi S1 Keperawatan STIKes Bhakti Mandala Husada Slawi
} 


\section{INTISARI: BERMAIN TERAPEUTIK CLAY MENURUNKAN TINGKAT KECEMASAN PADA ANAK USIA PRASEKOLAH SAAT TINDAKAN INJEKSI}

Latar Belakang : Anak yang dirawat di rumah sakit banyak yang mengalami kecemasan. Kecemasan pada anak tersebut disebabkan saat tindakan injeksi. Kecemasan pada anak ditandai dengan reaksi menolak, anak takut terhadap pengobatan yang diberikan, anak sering menangis dan tidak kooperatif pada petugas kesehatan. Untuk itu, diberikan terapi clay, dimana bermain dapat menjadikan diri anak lebih senang dan nyaman sehingga adanya stress dan ketegangan dapat dihindarkan.

Tujuan : Mengetahui pengaruh terapi clay terhadap tingkat kecemasan pada anak usia prasekolah saat tindakan injeksi di ruang Anggrek RSUD dr. Soeselo Slawi.

Metode Penelitian : Jenis penelitian kuantitatif, rancangan quasi experimental design dengan pendekatan one group pretest and posttest design. Sampel dalam penelitian ini adalah anak usia prasekolah sebanyak 20 responden. Instrumen yang digunakan adalah lembar observasi untuk mengetahui kecemasan dengan menggunakan Spence Children Anxiety Scale. Analisis data secara univariat (distribusi frekuensi) dan bivariate (wilxocon test).

Hasil : Hasil dari uji Wilcoxon test dengan menggunakan program komputer pada tingkat kesalahan $5 \%(\rho-0.05)$ di peroleh $\rho$ value $=0.002$ sehingga $\rho$ value $<\rho$ yaitu $(0.002<0.05)$ yang berarti Ha diterima dan artinya ada pengaruh bermain terapeutik clay terhadap tingkat kecemasan pada anak usia prasekolah saat tindakan injeksi di ruang Anggrek RSUD dr. Soeselo Slawi.

Kesimpulan : ada pengaruh bermain terapeutik clay terhadap tingkat kecemasan pada anak usia prasekolah saat tindakan injeksi di ruang Anggrek RSUD dr. Soeselo Slawi.Rekomendasi dari penelitian ini adalah clay dapat diberikan pada anak usia prasekolah untuk mengurangi kecemasan saat tindakan injeksi.

Kata Kunci : Bermain, Clay, Injeksi, Kecemasan

\section{PENDAHULUAN}

Anak usia prasekolah merupakan anak yang berada pada rentang usia 3 hingga 6 tahun. Anak usia prasekolah mempunyai pemikiran egosentrik, imajinaf dan fantasi yang liar (Kyle \& Carman, 2015). Hal ini sesuai dengan teori dari Supartini (2012) bahwa pertumbuhan dan perkembangan anak usia prasekolah sudah lebih aktif, kreatif dan imajinati. Pada masa usia prasekolah ini aktifitas anak yang meningkat menyebabkan anak sering kelelahan sehingga menyebabkan rentan terserang penyakit akibat daya tahan tubuh yang lemah pula, hingga anak diharuskan untuk menjalani hospitalisasi. Pada saat proses inilah terkadang anak mengalami berbagai pengalaman yang sangat traumatis dan penuh dengan stres. Stress pada anak ini dapat diperlihatkan dengan kecemasan yang muncul pada sikap anak (Rasmun, 2009).

Di Indonesia jumlah kunjungan pasien anak untuk rawat inap di rumah sakit tahun 2010 adalah 1.699.934 sedangkan tahun 2011 sejumlah 1.204.612 dan hampir semua

Anisa Oktiawati ${ }^{1}$, Wisnu Widyantoro ${ }^{2}$, Ayu Mey Fahmi Fardlillah ${ }^{3}$

${ }^{1}$ Dosen STIKes Bhakti Mandala Husada Slawi. Email : anisaoktiawati1586@gmail.com

${ }^{2}$ Dosen Program Studi S1 Keperawatan STIKes Bhakti Mandala Husada Slawi

${ }^{3}$ Mahasiswa Program Studi S1 Keperawatan STIKes Bhakti Mandala Husada Slawi 
anak usia prasekolah yang di rawat di rumah sakit mengalami kecemasan terutama saat dilakukan injeksi (Kemenkes RI, 2012). Rawat inap di rumah sakit sering disebut Hospitalisasi. Hospitalisasi merupakan kondisi yang sulit bagi anak, khususnya anak prasekolah karena lingkungan yang asing, kebiasaan yang berbeda serta perpisahan dengan orangtua. Kecemasan yang dialami anak hospitalisasi dapat menimbulkan dampak diantaranya proses penyembuhan anak dapat terhambat, menurunnya semangat untuk sembuh dan tidak kooperatifnya anak terhadap tindakan perawatan (Supartini, 2012).

Reaksi anak terhadap sakit adalah kecemasan karena perlukaan tubuh dan rasa nyeri saat tindakan injeksi. Pemberian injeksi obat intravena adalah salah satu prosedur yang sering diberikan pada anak saat dirawat dan akan menimbulkan kecemasan. Kecemasan yang terjadi pada anak tidak dapat dibiarkan, karena hal ini dapat berdampak buruk pada proses pemulihaan kesehatan anak. Dalam mengatasi kecemasan ini salah satu hal yang dapat dilakukan ialah melalui bermain terapeutik. Bermain terapeutik merupakan bentuk aktivitas permainan terstruktur berfokus untuk mengurangi rasa takut dan kekhawatiran akibat hospitalisasi pada anak (Oktiawati \& Julianti, 2019). Permainan anak akan membuat anak terlepas dari ketegangan dan stres yang dialaminya karena dengan melakukan permainan, anak akan dapat mengalihkan rasa sakitnya pada permainannya dan relaksasi melalui kesenangannya melakukan permainan (Supartini, 2012).

Pada masa prasekolah jenis permainan salah satunya adalah skill play. Skill play memberikan kesempatan pada anak untuk memperoleh ketrampilan tertentu dan anak dapat melakukan berulang-ulang (Oktiawati,Khodijah, Setyaningrum \& Dewi, 2017). Salah satu permainan skill play adalah bermain clay. Terapi clay merupakan jenis terapi bermain kreativitas seni dan keahlian. Bermain terapeutik dengan menggunakan clay sangat tepat karena clay tidak membutuhkan energi yang besar untuk bermain, meningkatkan kemampuan anak dalam memecahkan masalah, menurunkan kecemasan, pengendalian impuls dan kemarahan (Sholt \& Gavron, 2006).

Hasil penelitian Kodiriya et al., (2019) menyatakan bahwa terapi clay dan origami efektif untuk menurunkan kecemasan akibat hospitalisasi. Penelitian ini dilakukan selama 20 menit selama 3 hari, hasilnya anak tidak mengalami ketakutan dan mau berkomunikasi dengan peneliti. Pada penelitian ini dilakukan kombinasi antara bermain clay dan origami, 10 menit dilakukan permainan clay dan 10 menit dilakukan permainan origami. Penelitian lain dari Ariyanthi, Kusmiran \& Septiani (2014) menunjukkan bahwa terdapat penurunan kecemasan pada kelompok clay dibandingkan kelompok mewarnai. Hal ini dikarenakan jenis permainan clay mengutamakan perpaduan warna, anak menjadi imajinatif karena dapat membentuk sesuatu yang di inginkan serta meningkatkan kreatifitas anak terlihat saat anak memainkan clay tersebut.

Penelitian yang penulis lakukan memiliki persamaan dan perbedaan dengan penelitian sebelumnya.

Penelitian sebelumnya dari Lukitasari (2019) meneliti tentang pengaruh clay terhadap kecemasan anak usia prasekolah yang menjalani prosedur invasif. Penelitian ini menggunakan jenis penelitian quasi experimental dengan kontrol dan

Anisa Oktiawati ${ }^{1}$, Wisnu Widyantoro ${ }^{2}$, Ayu Mey Fahmi Fardlillah ${ }^{3}$

${ }^{1}$ Dosen STIKes Bhakti Mandala Husada Slawi. Email : anisaoktiawati1586@gmail.com

${ }^{2}$ Dosen Program Studi S1 Keperawatan STIKes Bhakti Mandala Husada Slawi

${ }^{3}$ Mahasiswa Program Studi S1 Keperawatan STIKes Bhakti Mandala Husada Slawi 
teknik pengambilan sampel consecutive sampling sedangkan penelitian yang penulis lakukan menggunakan jenis penelitian quasi experimental design dengan pendekatan one group pretest and posttest design dan dengan metode pengambilan sampel purposive sampling. Penelitian ini memiliki kesamaan dengan penelitian yang dilakukan penulis yaitu responden anak usia prasekolah (4-6 tahun). Penelitian lain dari Dayani, Budiarti, \& Lestari (2015) meneliti tentang terapi bermain clay terhadap kecemasan pada anak usia prasekolah (3-6 tahun) yang menjalani hospitalisasi. Penelitian ini memiliki persamaan variable yaitu terapi clay dan kecemasan pada anak usia prasekolah. Sedangkan Perbedaannya adalah rancangan penelitian yang dilakukan penelitian ini menggunakan quasi experimental design dengan pendekatan one group pretest and posttest design sedangkan pada penelitian sebelumnya menggunakan rancangan Pretest-Posttest Non Equivalent Control Group Design.

Berdasarkan hasil observasi pada anak terlihat bahwa saat akan dilakukan injeksi reaksi mereka yaitu takut terhadap pengobatan yang diberikan, reaksi menolak, takut, anak sering menangis dan tidak kooperatif pada petugas kesehatan. Di rumah sakit belum ada program terapi bermain yang khusus dilakukan oleh petugas kesehatan di RSUD dr. Soeselo Slawi, terapi bermain hanya dilakukan oleh Mahasiswa keperawatan yang melakukan praktik itupun kalau sedang ujian dan belum pernah dilakukan terapi bermain menggunakan lilin. Perbedaan dengan Penelitian sebelumnya adalah dilakukan untuk mengatasi kecemasan karena hospitalisasi. Oleh karena itu untuk mengatasi kecemasan tersebut perawat berperan penting dalam upaya meminimalisasikan kecemasan saat penyuntikan salah satunya adalah dengan cara memberikan terapi bermain.

\section{METODE PENELITIAN}

Jenis penelitian yang digunakan adalah quasi experimental design dengan pendekatan one group pretest and posttest design. Sampel dalam penelitian ini seluruh pasien anak usia pra sekolah yang dirawat inap di ruang Anggrek RSUD Dr. Soeselo Slawi, dengan jumlah 20 yang diambil dengan teknik sampling nonprobability sampling jenis purposive sampling. Kriteria inklusi dalam penelitian ini adalah Pasien dengan usia prasekolah 3-6 tahun yang berjenis kelamin laki - laki dan perempuan, Pasien yang diinjeksi melalui IV atau bolus, Pasien yang dilakukan peawatan dirumah sakit maksimal 3 hari, Pasien dalam kondisi sadar atau tidak dalam keadaan koma dan Orangtua setuju anaknya sebagai responden. Sedangkan Kriteria eksklusi dalam penelitian ini adalah Responden dengan penyakit kronik dan Responden yang tidak dapat diajak berinteraksi.

Alat dan bahan yang digunakan adalah clay berwarna-warni, plastic, tissue basah dan kering, cetakan, handsanitazer. Instrumen yang digunakan adalah lembar observasi untuk mengetahui kecemasan dengan menggunakan Spence Children Anxiety Scale yang telah di modifikasi oleh Saputro \& Fazrin (2017) dalam buku tentang anak sakit wajib bermain di rumah sakit beruba 15 item pernyataan.

Proses pengumpulan data dilakukan selama 3 hari. Hari pertama sebelum diberikan clay orangtua diberikan lembar observasi tentang kecemasan saat sebelum dilakukan

Anisa Oktiawati ${ }^{1}$, Wisnu Widyantoro ${ }^{2}$, Ayu Mey Fahmi Fardlillah ${ }^{3}$

${ }^{1}$ Dosen STIKes Bhakti Mandala Husada Slawi. Email : anisaoktiawati1586@gmail.com

${ }^{2}$ Dosen Program Studi S1 Keperawatan STIKes Bhakti Mandala Husada Slawi

${ }^{3}$ Mahasiswa Program Studi S1 Keperawatan STIKes Bhakti Mandala Husada Slawi 
tindakan injeksi, kemudian anak diberikan terapi clay. Pada hari kedua saat dilakukan tindakan injeksi anak diberikan bermain terapeutik clay. Pada hari ketiga saat anak diberikan injeksi diberikan bermain terapeutik clay, setelah itu orangtua mengisi lembar observasi kembali tentang kecemasan anak. Teknik pengolahan data meliputi editing, coding, entry data, tabulating, scoring dan cleaning. Etika penelitian ini telah berpedoman pada prinsip etik penelitian yaitu prinsip respect for human dignity, Respect for privacy and confidentiality dan beneficence. Analisa bivariate yang digunakan adalah uji Wilcoxon test.

\section{HASIL}

\section{Analisis Univariat}

1. Tingkat Kecemasan Anak Usia Prasekolah Sebelum Diberikaß Bermain Terapeutik Clay Saat Tindakan Injeksi.

Tabel 1. Distribusi frekuensi tingkat kecemasan anak usia prasekolah sebelum diberikan bermain terapeutik clay saat tindakan injeksi
Bermain Terapeutik Clay Saat Tindakan Injeksi.

Tabel 2. Distribusi Frekuensi Tingkat Kecemasan Anak Usia Prasekolah Sesudah Diberikan Bermain Terapeutik Clay Saat Tindakan Injeksi

\begin{tabular}{lll}
\hline \multicolumn{1}{c}{ Tingkat Kecemasan } & $(\mathrm{n})$ & Prosentase(\%) \\
\hline Kecemasan Ringan & 13 & $65 \%$ \\
Kecemasan Sedang & 4 & $20 \%$ \\
Kecemasan Berat & 3 & $15 \%$ \\
\hline Total & 20 & $100 \%$ \\
\hline
\end{tabular}

Berdasarkan tabel 2 di atas menunjukan tingkat kecemasan anak usia prasekolah sesudah diberikan bermain terapeutik clay saat injeksi dari 20 responden sebanyak 3 responden (15\%) mengalami kecemasan berat.

Distribusi Frekuensi Tingkat Kecemasan Anak Usia Prasekolah Sebelum dan Sesudah Diberikan Bermain Terapeutik Clay Saat Tindakan Injeksi

Tabel 3. Distribusi Frekuensi Tingkat Kecemasan Anak Usia Prasekolah Sebelum dan Sesudah Diberikan

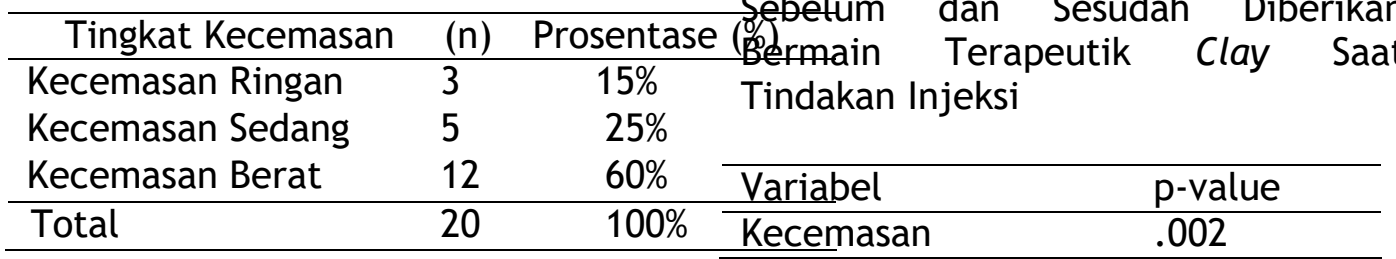

Berdasarkan tabel 1 di atas menunjukan tingkat kecemasan anak usia prasekolah sebelum diberikan bermain terapeutik clay saat injeksi dari 20 responden sebanyak 12 responden $(60 \%)$ mengalami kecemasan berat.

2. Tingkat Kecemasan Anak Usia Prasekolah Sesudah Diberikan

Berdasarkan tabel 3 diatas hasil penelitian dari 20 responden menunjukan bahwa didapatkan uji Wilcoxon test . diperoleh $\mathrm{p}$-value $0,002<0,05$ yang berarti Ho ditolak dan Ha diterima atau dapat diartikan bahwa ada pengaruh bermain terapeutik clay terhadap tingkat kecemasan pada anak usia prasekolah saat tindakan injeksi di ruang anggrek RSUD dr. Soeselo Slawi.

Anisa Oktiawati ${ }^{1}$, Wisnu Widyantoro ${ }^{2}$, Ayu Mey Fahmi Fardlillah ${ }^{3}$

${ }^{1}$ Dosen STIKes Bhakti Mandala Husada Slawi. Email : anisaoktiawati1586@gmail.com

${ }^{2}$ Dosen Program Studi S1 Keperawatan STIKes Bhakti Mandala Husada Slawi

${ }^{3}$ Mahasiswa Program Studi S1 Keperawatan STIKes Bhakti Mandala Husada Slawi 


\section{PEMBAHASAN}

1. Tingkat Kecemasan Anak Usia Prasekolah Sebelum Diberikan Bermain Terapeutik Clay Saat Tindakan Injeksi.

Berdasarkan tingkat kecemasan anak usia prasekolah sebelum diberikan bermain terapeutik clay saat injeksi dari 20 responden sebanyak 12 responden $(60 \%)$ mengalami kecemasan berat. Kecemasan yang ditunjukkan anak prasekolah selama menjalani hospitalisasi pada penelitian ini sebagian besar disebabkan karena perpisahan, perlukaan tubuh dan rasa nyeri. Pada masa prasekolah reaksi anak terhadap tindakan invasif khususnya pada pemberian obat injeksi adalah takut dan menangis. Kecemasan yang terjadi pada anak tidak dapat dibiarkan, karena hal ini dapat berdampak buruk pada proses pemulihan kesehatan anak. Sehingga perawatan di rumah sakit akan menjadikan anak tersebut kehilangan kontrol dan pembatasan aktivitas (Junaidi, 2013).

Sejalan dengan penelitian yang dilakukan oleh Sutrisno et al., (2017) tentang kecemasan anak usia prasekolah sebelum dan sesudah diberikan terapi bermain saat pemberian obat injeksi, diketahui bahwa dari 17 responden rata-rata skor kecemasan sebelum diberikan intervensi dengan skala kecemasan ringan adalah 2 , kecemasan sedang 4 dan kecemasan berat 11 . Orang tua responden mengatakan anaknya mengalami kegelisahan, rasa takut, kerisauan dan kecemasan ketika menghadapi tindakan yang diartikan sebagai sesuatu yang menyakiti, memberikan ancaman.

Pada tabel 1 dapat dijabarkan bahwa dari 20 anak usia prasekolah menjadi subjek penelitian, sebelum diberikan terapi bermain clay oleh peneliti sebanyak 12 anak (60\%) menunjukan kecemasan berat dilihat dari kategorinya mayoritas anak memiliki tingkat kecemasan yang cukup tinggi sebelum diberikan terapi bermain mewarnai. Hal serupa juga ditemui pada peneltian Solikhah (2011) yaitu tingkat kecemasan anak usia pra sekolah sebelum diberikan intervensi terapi bermain mengalami kecemasan dengan kategori tingkat kecemasan sedang.

Peneliti berpendapat bahwa kecemasan pada saat perawat masuk ke dalam ruangan dan mendekati anak, reaksi yang selalu muncul dari anak yaitu ekspresi wajah anak yang tegang, memegangi atau mendekati orang tua atau saudaranya bahkan ada juga beberapa anak yang langsung mejerit, menangis dan anak merasa takut akan sakitnya di injeksi. Sedangkan pada saat perawat melakukan tindakan injeksi reaksi yang paling sering muncul pada anak yaitu ekspresi wajah tegang dan pucat, anak menangis, memegang erat atau memanggil - manggil orang tuanya.

\section{Tingkat Kecemasan Anak Usia Prasekolah Sesudah Diberikan Bermain Terapeutik Clay Saat Tindakan Injeksi.}

Berdasarkan tabel 2 tingkat kecemasan anak usia prasekolah sesudah diberikan bermain terapeutik clay saat injeksi dari 20 responden sebanyak 3 responden (15\%) mengalami kecemasan berat. Kecemasan yang terjadi pada anak tidak dapat dibiarkan, karena hal ini dapat berdampak buruk pada proses pemulihan kesehatan anak. Mengatasi kecemasan dapat dialihkan dengan berbagai cara salah satunya dengan bermain terapeutik. Bermain terapeutik merupakan bermain pada anak yang menjalani hospitalisasi.

Anisa Oktiawati ${ }^{1}$, Wisnu Widyantoro ${ }^{2}$, Ayu Mey Fahmi Fardlillah ${ }^{3}$

${ }^{1}$ Dosen STIKes Bhakti Mandala Husada Slawi. Email : anisaoktiawati1586@gmail.com

${ }^{2}$ Dosen Program Studi S1 Keperawatan STIKes Bhakti Mandala Husada Slawi

${ }^{3}$ Mahasiswa Program Studi S1 Keperawatan STIKes Bhakti Mandala Husada Slawi 
Permainan akan mengurangi kecemasan dan stress pada anak (Supartini, 2012).

Kecemasan yang dialami anak saat tindakan injeksi dapat menimbulkan dampak diantaranya proses penyembuhan anak dapat terhambat, menurunnya semangat untuk sembuh dan tidak kooperatifnya anak terhadap tindakan perawatan. Berbagai alasan yang dapat menyebabkan ketakutan/kecemasan anak saat tindakan injeksi, antara lain : takut nyeri setelah injeksi, takut terjadi komplikasi akibat injeksi atau penyakit, prosedur yang menyakitkan (Susilowati, \& Dwi, 2015).

Hasil penelitian dari Alini (2017) diketahui bahwa terjadi penurunan tingkat kecemasan pada anak usia prasekolah yang mengalami hospitalisasi setelah diberikan terapi bermain playdought. Terapi bermain playdought dapat menurun karena terapi tersebut dapat membantu anak dalam mengekpresikan perasaannya melalui bermain sehingga anak menjadi lebih nyaman. Penelitian lain dari Linda et al., (2018) menyatakan bahwa terapi bermain clay ini menarik bagi anak dengan warna-warna dan anak dapat menuangkan kreativitasnya saat bermain clay dengan membentuk hal yang diinginkan.

Peneliti berpendapat bahwa sesudah anak diberikan bermain terapeutik clay terjadi penurunan tingkat kecemasan dimana dari 20 anak yang diobservasi, tingkat kecemasan berat menjadi 3 anak (15\%). Melihat hasil tersebut, dapat ditarik kesimpulan bahwa sesudah dilakukan bermain terapeutik clay tingkat kecemasan anak mengalami penurunan. Sesudah diberikan bermain terapeutik clay saat injeksi kecemasan anak berkurang hal ini dimungkinkan anak merasa senang ketika diberikan permainan clay karena dengan pengalihan bermain terapeutik clay.

\section{Distribusi Frekuensi Tingkat Kecemasan Anak Usia Prasekolah Sebelum dan Sesudah Diberikan Bermain Terapeutik Clay Saat Tindakan Injeksi}

Pemberian bermain terapeutik clay dapat menurunkan tingkat kecemasan usia prasekolah selama menjalani perawatan di rumah sakit. Hasil penelitian dari 20 responden menunjukan bahwa didapatkan anak usia prasekolah sebelum diberikan bermain terapeutik clay saat tindakan injeksi yang mengalami kecemasan berat 12 responden dan sesudah diberikan bermain terapeutik clay saat tindakan injeksi yang mengalami kecemasan berat menurun menjadi 3 responden. Dan didapatkan uji Wilcoxon test . diperoleh p-value $0,02<0,05$ yang berarti Ho ditolak dan Ha diterima atau dapat diartikan bahwa ada pengaruh bermain terapeutik clay terhadap tingkat kecemasan pada anak usia prasekolah saat tindakan injeksi di ruang anggrek RSUD dr. Soeselo Slawi.

Anak yang dirawat dirumah sakit sebagian besar akan menjalani prosedur invasif seperti pemberian injeksi. Tindakan pemberian injeksi merupakan stressor bagi anak karena akan menyebabkan anak menjadi trauma dan nyeri pada area penyuntikan. Anak prasekolah akan merasakan ketakutan yang berlebihan jika saat injeksi mengakibatkan seperti kulit terbakar. Hasil penelitian yang dilakukan oleh Bisogni et al., (2014) bahwa sebagian anak dapat mentoleransi prosedur invasif, meskipun ada anak yang menunjukkan antisipasif terhadap tindakan sehingga

Anisa Oktiawati ${ }^{1}$, Wisnu Widyantoro ${ }^{2}$, Ayu Mey Fahmi Fardlillah ${ }^{3}$

${ }^{1}$ Dosen STIKes Bhakti Mandala Husada Slawi. Email : anisaoktiawati1586@gmail.com

${ }^{2}$ Dosen Program Studi S1 Keperawatan STIKes Bhakti Mandala Husada Slawi

${ }^{3}$ Mahasiswa Program Studi S1 Keperawatan STIKes Bhakti Mandala Husada Slawi 
nyeri dan gelisah selama prosedur akan meningkat.

Hal ini sesuai dengan penelitian Dayani, Budiarti \& Lestari (2015) menyatakan bahwa terdapat pengaruh terapi bermain clay terhadap kedemasan pada anak usia prasekolah di RSUD Banjarbaru, karena dengan anak melakukan bermain dapat mengalihkan perhatian akibat hospitalisasi. Hal ini juga sejalan dengan penelitian Kumar (2019) bahwa perbedaan skor rata-rata kecemasan pada kelompok anak yang tidak diberikan terapi clay adalah 138,73 dan 40,49 sedangkan pada kelompok anak yang diberikan terapi clay adalah 93,9 dan 34,58, terbukti bahwa terdapat perbedaan yang signifikan antara kelompok yang diberikan dan tidak diberikan terapi clay. Hasil penelitian ini mengungkapkan bahwa anak yang menerima terapi clay memiliki penurunan kecemasan yang signifikan secara statistik. Terapi clay sangat dianjurkan karena efektif, murah, dan mudah dilakukan.

Hasil penelitian lain tentang terapi clay oleh Rahmania \& Moheba (2010) menyatakan bahwa terapi clay dan terapi narasi dapat menurunkan gejala kecemasan dan dapat meningkatkan harga diri dan sosialisasi pada anak. Hal ini juga sesuai dengan penelitian Lukitasari (2019) yang menunjukkan bahwa terdapat pengaruh clay therapy terhadap kecemasan anak usia prasekolah dengan tingkat rata-rata kecemasan adalah 7,82 dan mengalami penurunan menjadi 5,29. Hasil ini sesuai dengan pengamatan yang terjadi dilapangan bahwa anak yang dilakukan tindakan invasit sebagian besar rileks ketika diberikan bermain clay dan anak menunjukkan kesenangannya. Pada kondisi rileks tubuh anak akan mengeluarkan opiot endorfin yang menyebabkan anak menjadi senang.

Berdasarkan hasil penelitian, maka peneliti berpendapat bahwa ada pengaruh sebelum dan sesudah dibermain terapeutik clay terhadap tingkat kecemasan pada anak usia prasekolah saat tindakan injeksi di ruang Anggrek RSUD dr. Soeselo Slawi bahwa anak pra sekolah, selain itu dapat pula meningkatkan asuhan keperawatan khususnya pada keperawatan anak sehingga menurut peneliti bahwa sangat penting penerapan bermain terapeutik pada anak usia pra sekolah selama dirawat di rumah sakit.

\section{KESIMPULAN}

Ada pengaruh bermain terapeutik clay terhadap tingkat kecemasan pada anak usia prasekolah saat tindakan injeksi di ruang anggrek RSUD dr. Soeselo Slawi. Rekomendasi dari penelitian ini adalah clay dapat diberikan pada anak usia prasekolah untuk mengurangi kecemasan saat tindakan injeksi.

\section{DAFTAR PUSTAKA}

Alini. (2017). Pengaruh Terapi Bermain Plastisin (Playdought) terhadap Kecemasan Anak Usia Prasekolah (3-6 tahun) yang Mengalami Hospitalisasi di Ruang Perawatan Anak RSUD Bangkinang Tahun 2017. Jurnal Ners Universitas Pahlawan Tuanku Tambusai, 1(1). https: / /doi.org/10.1017/CBO978 1107415324.004.

Ariyanthi, L., Kusmiran, E., \& Septiani, A. (2014). Pengaruh Bermain Teraupetik terhadap Tingkat Kecemasan Akibat Pemberian Injeksi Obat IV (Bolus) pada Anak Usia Prasekolah di Ruang Anak Rumah Sakit Umum

Anisa Oktiawati ${ }^{1}$, Wisnu Widyantoro ${ }^{2}$, Ayu Mey Fahmi Fardlillah ${ }^{3}$

${ }^{1}$ Dosen STIKes Bhakti Mandala Husada Slawi. Email : anisaoktiawati1586@gmail.com

${ }^{2}$ Dosen Program Studi S1 Keperawatan STIKes Bhakti Mandala Husada Slawi

${ }^{3}$ Mahasiswa Program Studi S1 Keperawatan STIKes Bhakti Mandala Husada Slawi 
Daerah Cibabat 2014. Jurnal Kesehatan Rajawali, 4(7).

Bisogni, S., Dini, C., Olivini, N., Ciofi, D., Giusti, F., Caprilli, S., Lopez, J. R. G., \& Festini, F. (2014). Perception of venipuncture pain in children suffering from chronic diseases. BMC Research Notes, $7(1)$, 1-6. https://doi.org/10.1186/17560500-7-735

Dayani, N.E., Budiarti, L, Y. \& Lestari, D. . (2015). Terapi Bermain Clay Terhadap Kecemasan Pada Anak Usia Prasekolah (3-6 Tahun) Yang Menjalani Hospitalisasi Di Rsud Banjarbaru. Dunia Keperawatan, 3(2), 1-15.

Junaidi. (2013). Pengaruh Terapi Bermain terhadap Respon Penerimaan Pemberian Obat Injeksi pada Anak Pra Sekolah di RSUD H. Padjonga DG. Ngalle Takalar. Jurnal IImiah Kesehatan, 2(2). http://ejournal.stikesnh.ac.id/in dex.php/jikd/article/view/403/2 87

Kemenkes RI. (2012). Laporan Nasional 2012.

Kodiriya, N. S., Munir, Z., Kholisotin, K., Fauzi, A. K., \& Wahid, A. H. (2019). The effectiveness of playing Clay and Origami therapy to reduce anxiety pediatric patients hospitalized. Jurnal Aisyah: Jurnal Ilmu Kesehatan, 4(2), 151-160. https://doi.org/10.30604/jika.v4 i2. 200 .

Kumar, S. (2019). Study to Assess the Effectiveness of Clay Therapy on Anxiety among Hospitalized
Preschool Children at Paediatric Medical ward in Institute of Child Health and Research Centre, Government Rajaji Hospital Madurai. International Journal of Pediatric Nursing, 5(1). http://nursing.journalspub.info/i ndex.php?journal=IJPN\&page $=$ arti cle\&top=view\&path\%5B\%5D=1026.

Kyle, T \& Carman, S. (2015). Buku Praktik Keperawatan Pediatrik. Jakarta. EGC.

Linda, K., Savitri, D., Kusumaningsih, F. S., Ayu, D., \& Rama, A. (2018). Pengaruh Clay Therapy Terhadap Perilaku Adaptif Pada Anak Usia Prasekolah Yang Mengalami Hospitalisasi. Community of Publishing in Nursing, 6(3), 2303-1298.

Lukitasari, D. (2019). Pengaruh Clay Therapy Terhadap Kecemasan Anak Usia Prasekolah Yang Menjalani Prosedur Invasif Di RSUD Al-Ihsan. Jurnal Sehat Masada, 13(2).

Oktiawati, A.,\& Julianti, E. (2019). Buku Ajar Konsep dan Aplikasi Keperawatan Anak. Jakarta. Trans Info Media.

Oktiawati, A., Khodijah. Setyaningrum, I., \& Dewi, R, C. (2017). Teori dan Konsep Keperawatan Pediatrik. Jakarta. Trans Info Media.

Rahmania, P., \& Moheba, N. (2010). The effectiveness of clay therapy and narrative therapy on anxiety of pre-school children: A comparative study. Procedia Social and Behavioral Sciences, 5 ,

23-27.

Anisa Oktiawati ${ }^{1}$, Wisnu Widyantoro ${ }^{2}$, Ayu Mey Fahmi Fardlillah ${ }^{3}$

${ }^{1}$ Dosen STIKes Bhakti Mandala Husada Slawi. Email : anisaoktiawati1586@gmail.com

${ }^{2}$ Dosen Program Studi S1 Keperawatan STIKes Bhakti Mandala Husada Slawi

${ }^{3}$ Mahasiswa Program Studi S1 Keperawatan STIKes Bhakti Mandala Husada Slawi 
https: / /doi.org/10.1016/j.sbspro .2010.07.044.

Saputro, H., \& Fazrin, I. (2017). Penurunan Tingkat Kecemasan Anak Akibat Hospitalisasi dengan Penerapan Terapi Bermain. Jurnal Konseling Indonesia (JKI), 3(31), $\quad 9-12$. http://ejournal.unikama.ac.id/in dex.php/JKI

Solikhah, U. (2011). Therapeutic Peer Play Sebagai Upaya Menurunkan Kecemasan Anak Usia Sekolah Selama Hospitalisasi. Jurnal Keperawatan Soedirman, 6(1), 111.

http://jks.fikes.unsoed.ac.id/ind ex.php/jks/article/view/320/163

Supartini, Y. (2012). Buku Ajar Konsep Dasar Keperawatan Anak. Jakarta. EGC.

Susilowati, E \& Dwi, R, M. (2015). Pengaruh Terapi Bermain Terhadap Penerimaan Tindakan Invasif pada Anak Pra Sekolah di IRNA RSUD Ngudi Waluyo, Wlingi, Blitar. Jurnal Ilmu Kesehatan, 3(2), 55-59. https://ejurnaladhkdr.com/index .php/jik/article/view/58/49

Sutrisno, S., Widodo, G. G., \& Susanto, H. (2017). Kecemasan Anak Usia Sekolah Sebelum dan Sesudah Mendapatkan Informasi Saat Pemberian Obat Injeksi. Jurnal Aisyah: Jurnal Ilmu Kesehatan, 2(2), 99-106. https: / / doi.org/10.30604/jika.v2 i2.42

Anisa Oktiawati ${ }^{1}$, Wisnu Widyantoro ${ }^{2}$, Ayu Mey Fahmi Fardlillah ${ }^{3}$

${ }^{1}$ Dosen STIKes Bhakti Mandala Husada Slawi. Email : anisaoktiawati1586@gmail.com

${ }^{2}$ Dosen Program Studi S1 Keperawatan STIKes Bhakti Mandala Husada Slawi

${ }^{3}$ Mahasiswa Program Studi S1 Keperawatan STIKes Bhakti Mandala Husada Slawi 